\title{
Effects of payment method on work control, work risk and work-related musculoskeletal health among sewing machine operators
}

\author{
R. Nawawi' ${ }^{1}$ B.M. Deros ${ }^{1 *}$, D.D.I. Daruis ${ }^{2}$, A. Ramli ${ }^{3}$, R.M. Zein ${ }^{4}$ and L.H. Joseph ${ }^{3}$ \\ ${ }^{1}$ Dept. of Mechanical and Materials Engineering \\ Faculty of Engineering \& Built Environment \\ Universiti Kebangsaan Malaysia, Malaysia \\ *Email: hjbaba@ukm.edu.my \\ ${ }^{2}$ Faculty of Engineering, Universiti Pertahanan Nasional Malaysia, Malaysia \\ ${ }^{3}$ Department of Physiotherapy \\ Faculty of Science, Lincoln University College, Malaysia \\ ${ }^{4}$ Department of Consultation, Research \& Development, \\ National Institute of Occupational Safety and Health (NIOSH), Malaysia
}

\begin{abstract}
This study aimed to identify payment method and its effects on work control, work risk and work-related musculoskeletal health among Malaysian sewing machine operators. The study sample comprised 337 sewing machine operators (male, $n=122$, female, $\mathrm{n}=215$; aged between 18-54 years old; mean $30.74 \pm 8.44$ ) from four different garmentmaking companies in Malaysia. They were being paid via time rate wages $(n=246)$ and piece rate wages $(n=91)$. Data was collected through Nordic Musculoskeletal Questionnaire and pen-and-paper assessment via Rapid Upper Limb Assessment (RULA). From the study, the piece rate wage group was found to take fewer breaks, had high work production demands, worked at a faster pace and experienced more exhaustion and pressure due to increasing work demands as compared to the time rate group. They were also observed working with higher physical exposure such as repetitive tasks, awkward static postures, awkward grips and hand movements, pulling, lifting and pushing as compared to those in the time rate wage group. The final RULA scores was also higher from the piece rate wage group (72.53\% RULA score 7$)$ which indicated higher work risks among them. The study found that the type of wage payment was significantly associated with work risks $(\mathrm{p}=0.036, \mathrm{df}=1)$ and WRMSD at the shoulder, lower back, forearm, and leg $(\mathrm{p}<0.005, \mathrm{df}=1)$. The musculoskeletal pain in these regions were reported more often by the piece rate wage group than the time rate wage group (At shoulder; OR $=2.94$ with $95 \%$ confidence interval $(\mathrm{CI}): 1.39-6.20$, at lower back OR $=3.16$ with $95 \%$ CI: $1.74-5.74$, at forearm OR $=2.55$ with $95 \% \mathrm{CI}$ : 1.56-4.17, at hip OR $=2.49$ with $95 \%$ CI: $1.52-4.07$ and at leg OR $=2.97$ with $95 \% \mathrm{CI}$ : 1.72-5.15). It can be concluded that the type of wage system could be one of the contributory factors in a high prevalence of WRMSD and high ergonomic physical work risks among sewing machine operators. It is recommended that sewing machine operators are better off being paid via a time rate wage system compared to a piece rate wage system to reduce work risks and WRMSD among them.
\end{abstract}

Keywords: Musculoskeletal disorders, sewing machine operators, risk factors, symptoms. 


\section{INTRODUCTION}

Work-related musculoskeletal disorders (WRMSDs) have been hugely reported among sewing machine operators employed in the garment industry [1, 2]. Studies from Denmark, Botswana and Slovenia demonstrated a high prevalence of WRMSDs among sewing machine operators due to awkward work postures [3-7], repetitive and precise hand work $[3,4,8]$. The lack of job control and working systems were also associated with WRMSD due to insufficient work-rest schedules and long working hours in shift work [1, 2, 9, 10], high job demands [3, 11] and low job satisfaction [11]. The relationship between job demands, job control and its effects on the health of workers was proposed in the Job Demand Control model (JDC) [12] and the Effort-Reward Imbalance at Work [13] model which was consistent with previous studies [14-16]. The models proposed high job demands with low job control that caused high strain jobs and physical illnesses among workers. Job control can buffer the negative effects on health [17] and method of wage payment.

Employers in Malaysia have different ways of paying their employees. Sewing machine operators have been paid via a piece rate or time rate wage system. Piece rate sewing machine operators are paid based on the total number of clothes that they produced and the high production demand may cause them to perform under inadequate work-rest schedules in order to increase production. On the other hand, the time rate sewing machine operators are paid based on the total number of working hours. They may tend to put in long working hours of shift work as they are required to achieve the targeted value of production predetermined by the employers. However, studies on the relationship between high production demand, lack of control in working schedules and the effects on workers' physical health remain sparse and fragmented. Previous studies showed that female sewing machine operators in a Los Angeles garment industry [18] and an Australian clothing industry [19] were paid via a piece rate wage system. The report showed high work strain and high musculoskeletal pain compared to time rate wage workers. These results were similar to studies among female migrant farm workers in California [20], general workers in England [21], road freight industry [22], logging contractors in British Columbia [23], the construction industry in Norway [24], brush cutters in Canada [25], and lumberjacks in New Zealand [26] which also found that the piece rate wage system contributed to a higher work strain effect on workers' health and safety compared to the time rate wage system.

These findings contradicted findings from the Fiji garment industry [27] which showed no marked difference in terms of negative effects on workers' health and safety between time rate and piece rate wage earners. However, the situation was not always like that as at times the piece rate wage system may have a negative influence on workers' health and safety [28]. The piece rate wage system increased work risks depending on the types of risk exposure, types of tasks and the individual response towards the instrument of control. Thus, the influence of the different wage systems on different levels of job demands and their effect on musculoskeletal health among sewing machine operators need to be examined further. This study aimed to describe the pattern of work-related musculoskeletal disorders among sewing machine operators paid via piece rate and time rate wages. The outcome of the findings would assist in ascertaining the best method of payment for the Malaysian garment-making workers. 


\section{METHODS AND MATERIALS}

\section{The workplace}

This cross-sectional study was conducted in garment-making factories located in the East Coast, West Coast as well as the North and South of Peninsular Malaysia. The subjects performed tasks such as cutting clothes to form patterns and sewing. Each sewing machine operator sewed ready-to-sew pieces with foot pedal sewing machines as illustrated in Figure 1.

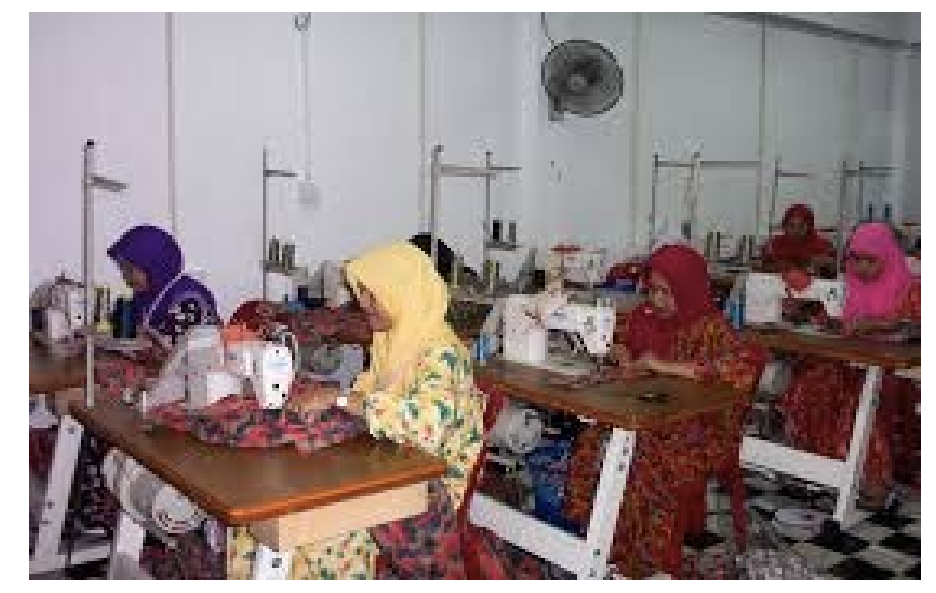

Figure 1. Foot pedal sewing machines.

\section{Subjects}

A total of 337 full-time sewing machine operators (male, $n=122$ and female, $n=215$ ) who were paid via a time rate wage system $(n=246)$ and a piece rate wage system $(n=91)$ were recruited from garment-making factories located at the East Coast, West Coast, as well as the North and South of Peninsular Malaysia. The full-time sewing machine operators aged between 18 and $54(30.74 \pm 8.44)$ with a minimum of one year's experience were selected based on the fact that their main task was operating the sewing machine, without considering whether they had musculoskeletal symptoms or not, except symptoms related to accidents and/or surgeries, and were not pregnant at the time of the study or in their sixth month of the post-partum period. The job specification and work environment were similar between the piece rate and time rate wage groups. Both groups of subjects performed similar sewing postural activities with monotonous, repetitive and precise hand work. They sat down on stools at their designated workstations and cut clothes to form patterns and sewed the ready-to-sew pieces. Their work duration differed between groups, based on different work-production demands depending on the method of payment of their wages. The time rate wage group worked 5-7 days per week, 8-13 hours per day with 75 minutes recess. Whereas, the piece rate wage group worked 6 days per week, 8 hours per day with 60 minutes recess time.

\section{Data Collection}

This paper only reported data that were obtained through a self-reported standardized Nordic Questionnaire [29] to examine the occurrence of musculoskeletal symptoms experienced by the subjects. Ergonomic risk factors were assessed among the subjects using Rapid Upper Limb Assessment (RULA) [30, 31]. This tool was used to assess postural loading on work-related disorders. Nordic Questionnaire and RULA have been 
used in other studies as tools to measure MS symptoms and postural concerns. Frequency of physical exposures experienced by the subjects was also quantified using self-administered questionnaire.

\section{Data Analysis}

Statistical analysis was performed on all the subjects using SPSS (version 21.0). Descriptive statistics of the general characteristics, work and workplace characteristics were presented in numbers, percentages and mean \pm standard deviations. The analytical statistics were carried out using chi-square tests to assess univariate associations between variables (type of wages and physical exposures), (types of wages and ergonomic risk factors) and (types of wages and musculoskeletal symptoms). The association [odd ratios (OR) and 95\% confidence intervals] between types of wages and prevalence of musculoskeletal symptoms in an unadjusted logistic regression model were estimated.

\section{RESULTS AND DISCUSSION}

Work Information of Piece Rate and Time Rate Wage Sewing Machine Operators Sewing machine operators with time rate wages were found to be working longer within a day and a week compared to the operators with piece rate wages (Table 1). It can be seen that the time rate wage group was more motivated to stay in work longer as they were paid on a time period basis while the piece rate wage group was more motivated to produce more pieces of clothing instead of staying in work longer. The study showed that the piece rate group had more years of experience in sewing because they needed to produce a greater number of quality clothing within supervised work time constraints (Table 2). The workers reported as shown in Table 3 that they had high job demands but fewer breaks to achieve predetermined production quotas. The major challenge facing clothing manufacturers was to produce more products using less material, less energy and less involvement of labour [32]. The wage system is one of the competitive strategies to compete in a dynamic market. However, Wang et al. [11] proposed that insufficient rest and high job demands lead to low job satisfaction. Hence, this could be a possible reason why the piece rate group felt more exhausted and pressured as compared to the time rate group The result was also supported by Madeleine [2] and Polajnar et al. [3] who reported that lack of work organization (such as shift length and work-rest schedules due to high job demands) was one of the causes for complaints of musculoskeletal symptoms.

\section{Wage Payment Method and Physical Exposure}

Both the piece rate group and time rate group performed similar sewing tasks in similar working environments. Despite that, the study reported that the piece rate group experienced a higher physical exposure to the development of MSD risks such as repetitive tasks, awkward static postures, awkward grips and hand movements, pulling, lifting and pushing as compared to the time rate group (Table 4). It can be seen in Table 4 that the piece rate group had more complaints about their physical exposure experience than the time rate group and this was significant at $\mathrm{p}<0.05$. All sewing machine operators who experienced prolonged sitting throughout their work reported WRMSD and this result was supported [3, 4, 8]. 
Table 1. Comparison of work duration between piece rate and time rate wage group.

\begin{tabular}{cccc}
\hline & Frequency & Piece rate group (\%)(n) & Time rate group (\%)(n) \\
\hline Working hours /day (hours) & $1-4$ & - & - \\
& $5-9$ & $100(91)$ & $9.35(23)$ \\
& $10-14$ & - & $90.65(223)$ \\
Working day /week (day) & $15-19$ & - & - \\
& 5 & $1.1(1)$ & $8.13(20)$ \\
& 6 & $98.9(90)$ & $89.83(221)$ \\
Total & 7 & - & $2.03(5)$ \\
& & $100(91)$ & $100(246)$ \\
\hline
\end{tabular}

Table 2. Comparison of work experience between piece rate wage workers and time rate wage workers.

\begin{tabular}{ccc}
\hline Work experience (years) & Piece rate wage $(\mathrm{n})$ & Time rate wage $(\mathrm{n})$ \\
\hline $1-4$ & 12 & 142 \\
$4-8$ & 10 & 89 \\
$8-13$ & 30 & 8 \\
$13-17$ & 25 & 4 \\
$17-21$ & 4 & 1 \\
$21-25$ & 10 & 2 \\
Total & 91 & 246 \\
\hline
\end{tabular}

Table 3. Rate of taking breaks, feeling exhausted and pressured during working hours between piece rate group and time rate group.

\begin{tabular}{ccccccccccc}
\hline & \multicolumn{10}{c}{ Frequency \% (n) } \\
\hline & $\begin{array}{c}\text { Niece } \\
\text { rate }\end{array}$ & $\begin{array}{c}\text { Time } \\
\text { rate }\end{array}$ & $\begin{array}{c}\text { Piece } \\
\text { rate }\end{array}$ & $\begin{array}{c}\text { Time } \\
\text { rate }\end{array}$ & $\begin{array}{c}\text { Piece } \\
\text { rate }\end{array}$ & $\begin{array}{c}\text { Time } \\
\text { rate }\end{array}$ & $\begin{array}{c}\text { Piece } \\
\text { rate }\end{array}$ & $\begin{array}{c}\text { Time } \\
\text { rate }\end{array}$ & $\begin{array}{c}\text { Piece } \\
\text { rate }\end{array}$ & $\begin{array}{c}\text { Time } \\
\text { rate }\end{array}$ \\
\hline Taking & $2.2(2)$ & 6.1 & 94.5 & 80.1 & 2.2 & 12.2 & 1.1 & - & 100 & 100 \\
breaks & & $(15)$ & $(86)$ & $(197)$ & $(2)$ & $(30)$ & $(1)$ & & $(91)$ & $(246)$ \\
Feeling & 2.2 & 26.4 & 69.2 & 49.2 & 16.5 & 11.4 & 12.1 & 13 & 100 & 100 \\
exhausted & $(2)$ & $(65)$ & $(63)$ & $(121)$ & $(15)$ & $(28)$ & $(11)$ & $(32)$ & $(91)$ & $(246)$ \\
Feeling & 5.5 & 25.2 & 87.9 & 49.2 & 5.5 & 12.6 & 1.1 & 13 & 100 & 100 \\
pressured & $(5)$ & $(62)$ & $(80)$ & $(121)$ & $(5)$ & $(31)$ & $(1)$ & $(32)$ & $(91)$ & $(246)$ \\
\hline
\end{tabular}

Table 4. Frequency of physical exposure experience within wage payment method.

\begin{tabular}{lcc}
\hline Physical exposure & Piece rate wage (\%) & Time rate wage (\%) \\
\hline Repetitive task & 100 & 98.8 \\
Fast-paced work & 98.9 & 100 \\
Static posture & 97.8 & 96.7 \\
Awkward posture & 100 & 94.3 \\
Prolong sit & 100 & 100 \\
Awkward grip & 97.8 & 93.5 \\
Awkward hand movement & 100 & 95.9 \\
Pulling & 93.4 & 72.2 \\
Lifting & 91.2 & 86.2 \\
Pushing & 48.4 & 41.6 \\
\hline
\end{tabular}




\section{Wage Payment Method and Work Risks}

It was seen from the study, that the sewing machine operators experienced more work risks during sewing with RULA scores 5-6 (to investigate further and change soon) and RULA score 7 (to investigate further and change immediately). None of the sewing machine operators from both groups experienced work risks with RULA Score 1-2 (acceptable work risk) and RULA 3-4 (to investigate further). The highest work risk (RULA score 7) showed that the sewing machine operators from the piece rate group suffered higher MSD (72.53\%) compared to the time rate group (60.16\%). Table 5 also showed that the second highest work risk (RULA score 5-6) were experienced more by the time rate group (39.84\%) than the piece rate group $(27.47 \%)$. This study showed that ergonomic risk factors experienced by sewing machine operators were associated with their wage payment method $(\mathrm{P}<0.05)(\mathrm{p}=0.036$, df $=1)$. The piece rate group were exposed with 0.57 higher work risks as compared to those in the time rate group OR $=$ 0.57 with $95 \%$ confidence interval CI: $0.34-0.97$. Therefore, the findings were in accordance with previous studies by Mirjana et al. [17] that sewing machine operators who were paid via the piece rate system experienced a higher risk of job strain due to their high job demands. This subsequently exposed the workers to adverse health effects.

Table 5. Ergonomic risk factors experienced by sewing machine operators.

\begin{tabular}{ccc}
\hline & \multicolumn{2}{c}{ Payment method (n (\%)) } \\
\hline RULA Score & Time rate wage & Piece rate wage \\
\hline $\begin{array}{c}\text { Score 7 } \\
\text { (investigate and change immediately) } \\
\text { Score 5-6 }\end{array}$ & $148(60.16 \%)$ & $66(72.53 \%)$ \\
(investigate and change soon) \\
Total & $98(39.84 \%)$ & $25(27.47 \%)$ \\
& $246(100 \%)$ & $91(100 \%)$ \\
\hline
\end{tabular}

\section{Wage Payment Method and Musculoskeletal Symptoms}

The highest frequency of musculoskeletal complaints was in the neck $(92.9 \%)$, followed by the shoulder $(79.5 \%)$, lower back (65.9\%), leg (59.3\%), upper back (48.4\%), knee (46.9\%), hip (43.0\%), elbow (37.1\%), forearm (36.5\% and wrist (31.5\%). The wage payment method was associated with pain in the shoulder, lower back, forearm, hip and leg $(\mathrm{p}<0.05, \mathrm{df}=1$ for all regions). The musculoskeletal pain in these regions were reported more often by the piece rate group as compared to the time rate group [whereas the shoulder odd ratio $(\mathrm{OR})=2.94$ with $95 \%$ confidence interval $(\mathrm{CI})$ : 1.39 6.20 ; in lower back $\mathrm{OR}=3.16$ with $95 \% \mathrm{CI}: 1.74-5.74$; in forearm $\mathrm{OR}=2.55$ with $95 \%$ CI: $1.56-4.17$; hip $\mathrm{OR}=2.49$ with $95 \% \mathrm{CI}: 1.52-4.07$ and leg $\mathrm{OR}=2.97$ with $95 \% \mathrm{CI}$ : 1.72-5.15]. This data is shown in Table 6. Therefore, the piece rate group was observed to be experiencing relatively higher workloads and higher musculoskeletal disorders. These findings were similar with a study conducted at the Los Angeles garment industry [18], Australian clothing industry [19] and also in the Job Demand control model (JDC) [12] and Effort-Reward Imbalance at work model [13]. The models stated that high job demands with low job control caused more strain resulting in physical illnesses among workers. Other studies also showed that the piece rate method resulted in more adverse effects in terms of health and safety among the workers [28]. Therefore it is concluded 
that the type of wage payment is one of the contributory factors that could result in negative effects especially on musculoskeletal health.

Table 6. Risk estimate of shoulder, lower back, forearm, hip and leg symptoms.

\begin{tabular}{lccc}
\hline Body Part & Odd ratio Value & 95\% Confidence Interval \\
\hline & & Lower & Upper \\
\hline Shoulder & 2.939 & 1.392 & 6.205 \\
Lower back & 3.157 & 1.738 & 5.734 \\
Forearm & 2.545 & 1.555 & 4.167 \\
Hip & 2.486 & 1.520 & 4.065 \\
Leg & 2.974 & 1.719 & 5.146 \\
\hline
\end{tabular}

\section{CONCLUSIONS}

Sewing machine operators with piece rate wages experienced relatively more work load and pressure due to increasing work demands. These subjects worked at a relatively faster pace and took fewer breaks throughout the duration of their work. They also worked with relatively high self-claimed physical exposure such as repetitive tasks, awkward static postures, awkward grips and hand movements, pulling, lifting and pushing. The study found that the piece rate group reported an overall higher frequency of musculoskeletal symptoms compared to the time rate group. The sewing machine operators with piece rate wages experienced relatively higher ergonomic concerns according to RULA analysis and reported of pain at the shoulder, low back, forearm, hip and leg. The most frequent complaints were for pain in the neck and shoulder area for the piece rate group where the OR value was 2.94 at $95 \%$ confidence level with CI 1.396.20. RULA observation also showed high value (7, investigate and change immediately). From this study it can be concluded that these sewing machine operators were better off being paid time rate wages rather than piece rate wages to reduce work risks and WRMSD among them.

\section{ACKNOWLEDGEMENTS}

We would like to thank all respondents who volunteered to participate in this study. The authors declare that there was no conflict of interest. The authors would also like to thank especially the National Institute of Occupational Safety and Health (NIOSH), Malaysia for providing the reseach fund under project code 01/NIOSH/03-01/NG0004.

\section{REFERENCES}

[1] Öztürk N, Esin MN. Investigation of musculoskeletal symptoms and ergonomic risk factors among female sewing machine operators in Turkey. International Journal of Industrial Ergonomics. 2011;41:585-91.

[2] Madeleine P. On functional motor adaptations: from the quantification of motor strategies to the prevention of musculoskeletal disorders in the neck-shoulder region. Acta Physiologica. 2010;199:1-46.

[3] Polajnar A, Leber M, Herzog NV. Muscular-skeletal diseases require scientifically designed sewing workstations. Strojniški vestnik-Journal of Mechanical Engineering. 2010;56:31-40. 
[4] Sealetsa O, Thatcher A. Ergonomics issues among sewing machine operators in the textile manufacturing industry in Botswana. Work. 2011;38:279-89.

[5] Kaergaard A, Andersen JH. Musculoskeletal disorders of the neck and shoulders in female sewing machine operators: prevalence, incidence, and prognosis. Occupational and Environmental Medicine. 2000;57:528-34.

[6] Kirin S, Dragčević Z. Investigation of workplace design for the process of sewing. Magic World of Textiles: Hrvatska znanstvena bibliografija i MZOSSvibor; 2008. p. 569-74.

[7] Rempel DM, Wang P-C, Janowitz I, Harrison RJ, Yu F, Ritz BR. A randomized controlled trial evaluating the effects of new task chairs on shoulder and neck pain among sewing machine operators: the Los Angeles garment study. Spine. 2007;32:931-8.

[8] Zhang F, He L, Wu S, Li J, Ye K, Wang S. Quantify work load and muscle functional activation patterns in neck-shoulder muscles of female sewing machine operators using surface electromyogram. Chinese Medical Journal. 2011;124:3731-7.

[9] Delleman NJ, Dul J. Sewing machine operation: workstation adjustment, working posture, and workers' perceptions. International Journal of Industrial Ergonomics. 2002;30:341-53.

[10] Raanaas RK, Anderson D. A questionnaire survey of Norwegian taxi drivers' musculoskeletal health, and work-related risk factors. International Journal of Industrial Ergonomics. 2008;38:280-90.

[11] Wang PC, Harrison RJ, Yu F, Rempel DM, Ritz BR. Follow-up of neck and shoulder pain among sewing machine operators: The Los Angeles garment study. American Journal of Industrial Medicine. 2010;53:352-60.

[12] Karasek R, Theorell T. Healthy work: stress, productivity, and the reconstruction of working life: Basic Books; 1992.

[13] Siegrist J. Adverse health effects of high-effort/low-reward conditions. Journal of Occupational Health Psychology. 1996;1:27.

[14] Bongers P, Ijmker S, Van den Heuvel S, Blatter B. Epidemiology of work related neck and upper limb problems: psychosocial and personal risk factors (part I) and effective interventions from a bio behavioural perspective (part II). Journal of Occupational Rehabilitation. 2006;16:272-95.

[15] De Lange AH, Taris TW, Kompier MA, Houtman IL, Bongers PM. The very best of the millennium: longitudinal research and the demand-control-(support) model. Journal of Occupational Health Psychology. 2003;8:282-305.

[16] Larsman P, Hanse JJ. The impact of decision latitude, psychological load and social support at work on the development of neck, shoulder and low back symptoms among female human service organization workers. International Journal of Industrial Ergonomics. 2009;39:442-6.

[17] Canjuga M, Läubli T, Bauer GF. Can the job demand control model explain back and neck pain? Cross-sectional study in a representative sample of Swiss working population. International Journal of Industrial Ergonomics. 2010;40:663-8.

[18] Wang P, Ritz B, Rempel D, Harrison R, Chan J, Janowitz I. Work organization and work-related musculoskeletal disorders for sewing machine operators in garment industry. Annals of Epidemiology. 2005;15:655.

[19] Quinlan M, Mayhew C. The effects of outsourcing on occupational health and safety: a comparative study of factory-based workers and outworkers in the 
Australian clothing industry. International Journal of Health Services. 1999;29:83-107.

[20] McCurdy SA, Samuels SJ, Carroll DJ, Beaumont JJ, Morrin LA. Agricultural injury in California migrant Hispanic farm workers. American Journal of Industrial Medicine. 2003;44:225-35.

[21] Lacey RJ, Lewis M, Sim J. Piecework, musculoskeletal pain and the impact of workplace psychosocial factors. Occupational Medicine. 2007;57:430-7.

[22] Quinlan M, Wright L. Remuneration and safety in the Australian heavy vehicle industry: A review undertaken for the National Transport Commission. Melbourne: National Transport Commision; 2008.

[23] Patterson PB. Attributions of danger and responses to risk among logging contractors in British Columbia's southern interior: Implications for accident prevention in the forest industry. Research in Economic Anthropology. 2007;26:103-25.

[24] Gravseth HM, Lund J, Wergeland E. Risk factors for accidental injuries in the construction industry. Tidsskrift for Den Norske Laegeforening: Tidsskrift for Praktisk Medicin, Ny Raekke. 2006;126:453-6.

[25] Toupin D, LeBel L, Dubeau D, Imbeau D, Bouthillier L. Measuring the productivity and physical workload of brushcutters within the context of a production-based pay system. Forest Policy and Economics. 2007;9:1046-55.

[26] Lilley R, Feyer A-M, Kirk P, Gander P. A survey of forest workers in New Zealand: Do hours of work, rest, and recovery play a role in accidents and injury? Journal of Safety Research. 2002;33:53-71.

[27] Chand A. At the bottom of a global commodity chain - how different really are hourly wage rates and piece rates? Industrial Relations Journal. 2012;43:171-91.

[28] Johansson B, Rask K, Stenberg M. Piece rates and their effects on health and safety-A literature review. Applied Ergonomics. 2010;41:607-14.

[29] Kuorinka I, Jonsson B, Kilbom A, Vinterberg H, Biering-Sørensen F, Andersson $\mathrm{G}$, et al. Standardised Nordic questionnaires for the analysis of musculoskeletal symptoms. Applied Ergonomics. 1987;18:233-7.

[30] McAtamney L, Corlett EN. RULA: A survey method for the investigation of work-related upper limb disorders. Applied Ergonomics. 1993;24:91-9.

[31] McAtamney L, Corlett EN. Reducing the risks of work related upper limb disorders: a guide and methods (second ed.): Institute for Occupational Ergonomics, University of Nottingham; 1996.

[32] Zuki NM, Mohamed N. Decomposition of manufacturing processes: A review. International Journal of Automotive and Mechanical Engineering. 2012;5:54560. 